\title{
STEMMING THE FALLING STANDARD OF ENGLISH: A SEMANTIC APPRAISAL OF PASSABLE BUT DEVIANT ENGLISH LANGUAGE USAGE IN ACADEMIA
}

\author{
K.O.O. Armah \\ Department of English, \\ Kwame Nkrumah University of Science and Technology, \\ Kumasi, Ghana
}

\begin{abstract}
This paper analyses some of the passable, albeit unacceptable, uses of English in academia and draws attention to the need to be conscious of the deviances. Some recurrent words and phrases have been picked from utterances of teachers, articles by journalists and essays of students for the study. The point is also made that, like Chinua Achebe (1974) who would seize an opportunity to remove 'structural weaknesses' from his Arrow of God, intellectuals should not see the acquisition of high qualifications as being necessarily the quintessence of knowledge, nor should deviant use of English be accepted in the name of so-called innovation. The dictionary form has been used to facilitate easy reference.
\end{abstract}

Keywords: academia, linguistics, intellectuals, nativisation, meaning, aberration.

\section{INTRODUCTION}

We are deliberately non-technical in this paper. Indeed, an article which seeks to unveil meaning cannot afford to use the complex and sophisticated jargons of modern grammars. Thus, we are largely straightforward in this presentation because any complexities might jeopardize our objective. If the re-awakening we seek to provoke is rude, it must at least also demonstrate our discomfiture with the movement towards total decay of the English language in Ghana and West Africa in general. Many intellectuals have expressed concern about the near-unstoppable deterioration in English language usage in Ghana. In most cases, the decay has been seen, perhaps without malice or pretence to selfsufficiency, only at the pre-tertiary levels of education. Hence, it is not uncommon to hear disparaging comments about low standards in basic and second cycle schools. The teachers are blamed for poor teaching and governments are berated for failure to ensure an environment conducive to effective teaching and learning. Books are inadequate while most teachers are illtrained, ill-equipped and ill-motivated. All these claims do have referential basis.

However, although it is the principal responsibility of the English language teacher to teach the language to students, all teachers in so far as 
their means of communication is English are, ipso facto, also teachers of the language. Therefore, the teacher whose medium of communication is English needs to ensure that they communicate meaningfully. This is because students tend to hold their teachers, especially University lecturers in high esteem and this makes the impressionable ones to imbibe whatever flows from them in terms of English language usage.

That is why in this paper we look at ourselves. We also seek to draw attention to the probability that as we climb the academic ladder we could unconsciously become set in our minds about certain linguistic constructions and usages which may be aberrations. We are often unable to know that they are aberrations. It takes another person's courageous effort and persuasion to make us know this and put ourselves in order. Such an effort is what we have tried to make in this paper, of course, not without extreme trepidation. We have carefully compiled scripts of students for some years now. The scripts have been meticulously analyzed to see errors and deviant usages which are common and the result has led us to several research possibilities. Indeed, we have had to look at such realities as the implications of the free use of all forms of English in academia, the influence of the electronic media, particularly the Frequency Modulation Stations and the print media. It is in the course of these investigations that we have found ourselves being compelled as it were, "to look again into our own inside".

In this paper we comment on some of the most common usages which many fail to see as deviant usage and our aim is to bring out the accepted meanings of such words and phrases as our contribution to stemming the gradual decay of the English language in Ghana and West Africa. In doing this we are cognizant of the move to nativise the English language in some countries. We know that, that effort would certainly give new meanings to some phrases, syntactic units or categories and some individual words. But until such new Englishes become legitimate as is the hope of the nativisors, the struggle to protect the English language must go on even if the crusaders would be charged with being snobbish or sanctimonious.

\section{DISCUSSION}

\section{Adopted Parents}

The constructions adopted parents, adopted father and adopted mother are often heard from even well-educated people and we sometimes read them in newspapers. None is correct. The question is, "who does the adoption?" Is it the child or the supposed parent?" We know that it is the adult, that is, the father, the mother or the parent who would adopt the child, the son or the daughter. Therefore, to describe a man or a woman who has adopted a child as an adopted parent is semantically faulty because it is illogical. We must say that a child never adopts a parent but a parent adopts a child. Thus, we cannot say the adopted parent but we can say the adopted child. If however, we insist on using the word adopt then the adjective adoptive is the correct word. We must therefore say adoptive parent, adoptive father, adoptive mother, adoptive family, et cetera. So the construction, "He was given to his adoptive family" is acceptable but "He was given to his adopted family" is unacceptable.

\section{ADVOCATE}

The word advocate is both a noun and a verb. The difference as to whether it is a verb or a noun in a particular usage is primarily phonetic. We need to understand this very well because most people are often confused as to whether this word requires a preposition to be meaningful. Let us take the liberty to do a rough transcribing here. If you pronounce the word advocate [aedvekeit], it is a verb but if you pronounce it [aedveket] it is a noun. As a verb it means public show of support for an action or plan. For example, "Mr Dan Lartey vigorously advocates the policy of domestication". But as a noun advocate refers to a person who openly shows support for a plan or action. For example, "Mr Dan Lartey is an advocate of the policy of domestication". 
However, our problem is that too often we read and hear the phrase advocate for in Educated Ghanaian and Nigerian English. For example, the following sentence appeared in an article in the Daily Graphic of May 24, 2007: "If Mr Adjei wants to advocate for recognizing Dr J. B. Danquah, he must do so directly and in a noncontroversial manner so as to win support for his arguments." This sentence was produced by a PhD and we can very well understand the surprise of the student who showed it to this researcher. It is wrong use of preposition. Certain English verbs never take prepositions in order to express their meanings. The verb advocate is one such verb. In our examples above therefore, if we are using the word as a verb then we will have the sentence,

Mr. Dan Lartey advocates the policy of domestication

\section{but never}

Mr. Dan Lartey advocates for the policy of domestication.

If we use the word as a noun we might have the sentence: "Mr Dan Lartey is an advocate of the policy of domestication. The difference then is that while as a noun advocate may be followed by a preposition as a verb it is not!

\section{AS AT NOW}

The usage of this phrase in West African English appears understandable. It is perceived as the equivalent of "as it is at the moment" or "at this particular moment, time etc". This kind of meaning given to expressions is what is described, not as a linguistic meaning but as speaker meaning by Akmajian et al. (2003). Time is the fulcrum in this usage. Quirk et al. (1972) explain that at, like on and in is a preposition of time. They specifically describe at, our main focus here, as a preposition of "Time when". According to them, at is used for points of time, chiefly clock time as in "ten o'clock, 6.30pm, at noon etc". They add that idiomatically at could also be used for holiday seasons as in "at the week-end, at Christmas, at Easter etc."
The operative word or factor then is time and this is where the problem is. Interestingly, Quirk et al do not mention the preposition of in their discussion of the preposition of time referred to earlier. This presents a difficulty for the nonnative speaker of English. Since at is a preposition of time then as at now ought to be an acceptable phrase because in using the phrase the non-native speaker's mind is on time. Thus, when non-native speakers say, "As at now we don't know what she has done to the baby" they simply mean "this present time or moment" when they are speaking. We must say though that time alone would decide the acceptability or otherwise of this phrase as a valid addition to the English Language. Perhaps, those who seek to nativise the language in their home countries would propagate its acceptance. But as with most idioms, we can only say that native speakers of English would normally say as of now but not as at now. In Standard English usage the correct preposition is of and not at. We must therefore learn to say and write:

a) As of $5^{\text {th }}$ January the new president had not been sworn into office.

b) He had not arrived as of the time I left the house.

c) As of now the situation is unclear.

d) As of press time the dismissal of the minister had not been officially announced.

However, as of can also mean as from. Here we mean that something will happen from a particular time onwards. Thus, we would say "As of next Academic Year University students will wear prescribed uniforms." This means that University students will wear prescribed uniforms as from the next academic year.

\section{BOTTLENECK}

"I can't allow reckless drivers to continue to kill our children. I will reduce the bottlenecks on this particular road", warned the minister. What is the Minister saying here? A bottleneck is an obstruction; if you reduce a bottleneck you increase the obstruction! This is an incontro- 
vertible fact though it seems paradoxical to those who see the word as a mere synonym for the word problem. For such people, if you say, "The bottleneck has been reduced", you mean "The problem has been reduced". This metaphor is often misused because its real meaning seems lost on most people. What is a bottleneck? This word describes a narrow point on a road. It is that part of a road which is so narrow that it is difficult or impossible for traffic to move freely. It also describes crossroads or where two roads meet. Clearly, such a place or point would compel all vehicles to slow down because a bottleneck is really an encumbrance. Can the consequence be imagined if that bottleneck is further reduced in size? In other words, since a bottleneck is an obstruction its reduction in size makes it narrower and that means the obstruction has been compounded but not reduced. What it means is that if we say we are reducing a bottleneck we are really saying we are worsening the problem. In fact, we can remove bottlenecks but we cannot reduce bottlenecks in the sense of reducing obstructions. We cannot therefore say, "The government has reduced all bottlenecks on the road militating against free flow of traffic and drivers are now comfortable". It does not make sense.

\section{COUP DETATS}

This is originally a French phrase which literally means a blow of state or a blow against state. It has a form similar to the English compound noun Head of Department or Head of State. As explained by Armah (2004), where we have a compound noun made up of a noun followed by a prepositional adjunct (Noun + Preposition + Noun), the first noun that is the base takes the $s$ sibilant suffix or the $s$-plural morpheme in plurality. We have a similar application as regards the pluralisation of the noun phrase coup de'tat. Journalists and other educated people have missed the plural form of this phrase many times. We have tended to add the $s$-plural morpheme to the last word, de'tat. For example, we often read and hear (a) J.J. Rawlings has staged two coup de'tats in Ghana (b) Africa has been bedeviled with too many coup de'tats since the sixties. These are incorrect constructions. The $s$ plural morpheme is rather added to the first noun coup to form the plural. So we say, "J.J. Rawlings has staged two coups de'tat in Ghana". We need to point out though that phonetically there is no difference between coup de'tat and coups de'tat. Both are pronounced, [ku:dei'ta:] which means that there is nothing like [ku: dei'tas] or [ku:s dei'ta] in the English Language! Thus, the difference between coup de'tat and its plural is merely orthographical.

\section{EKE OUT}

The word eke is not pronounced [ike] as we sometimes do. The correct pronunciation is $[i: k]$, something like [eek]. If we eke out something we make it last longer. For example, if our father finds that the bag of rice he has bought for the family is not enough and so buys a bag of gari he is eking out the rice with gari. Or, if just as we have sat down to eat fufu some friends arrive and announce that they are dying of hunger, we may be compelled to find some other food to supplement what we already have since what we have might be insufficient for us and our friends. If the other food we find is say, konkonte it means we have eked the fufu out with the konkonte. We can therefore say, "If the fufu is insufficient let's eke it out with konkonte". This means we are making the food we have sufficient by adding some other food. Again, eke out could mean "to economise". Frugality is the sense here. Thus, if we have to eke out a particular food item we are economizing that food item so that it would last longer. But we can also eke out a living. If your source of livelihood is insufficient but you manage to survive you eke out a living. In other words, you manage to survive in spite of your meagre income or resources. We can say, "Nowadays teachers reject the promise of having to eke out a living on poor salaries".

\section{IN JESUS NAME}

Let us suppose that the Biblical John came not as the Baptist but as the Christ. Obviously, he 
would have been known and called John the Christ or simply, John Christ. Since Christians pray, heal, testify, curse evil and cure diseases in the name of Jesus they would have likewise done these in the name of John. If we say in the name of Jesus or in the name of John, we are using what is called "the of-genitive". The genitive case shows possession and it has two forms, namely, "the of-genitive" and "the apostrophe plus $s$ ", that is, the apostrophe-s or the $s$ apostrophe, ('s or s'). Hence,

a) In the name of Jesus is the same as in Jesus's name or in Jesus' name.

b) In the name of John is also the same as in John's name.

However, if we say IN JESUS NAME as most Christians do, we risk also saying IN JOHN NAME! The absurdity is crystal clear in both speech and writing. Let us therefore write and say in Jesus's name or in Jesus' name which, in either case, must be pronounced IN JESUZIZ NAME. Clearly, it is simpler to use the "ofgenitive" as in, in the name of Jesus. Indeed, to remove the genitive aspect from the phrase by saying in Jesus name is to corrupt language.

\section{MATURED}

a) Mr. J.H. Mensah is a matured politician.

b) I entered the University as a matured student.

c) As a matured girl you should know that boys could be dubious.

d) "We have seen the losers openly congratulating the victors, which is the hallmark of matured politicians and this can be traced to the President's maturity in handling internal party matters". (Daily Guide, February 23, 2006)

None of the above sentences is correct; the past tense of mature cannot be used this way. Let us look at the following sentence or definition taken from the BBC English Dictionary (1992): "In a British college or university, a mature student is someone who starts doing their first degree when they are over 21 years old". Note here that the phrase is mature student and NOT matured student. The same dictionary explains that, "To mature means to develop or to reach a state of complete development" and gives the following important example: "...the great casks where the wine matured". Here, the word mature is a verb. Let us look carefully at the word mature as used in our examples, a to $\mathbf{d}$. Is the word being used as a verb, an adjective or as a noun? The answer is obvious: a verb. But the verb (to) mature cannot be used as has been used in the examples above because it occupies the position of an adjective and tense does not apply to the adjective! We need to be very careful with words which could be verbs as well as adjectives. When such words occupy the position of adjectives tense has no business being there. Thus, it is clear that the word mature as used in our examples a to $\mathbf{d}$ above is a verb wrongly placed because it is occupying the position of an adjective unnecessarily. In the example "As a matured girl you should know that boys could be dubious", the obvious connotation is that the girl, like wine, has been developed by an agent. This is wrong usage of the word mature which appears to have been confused with the verb nurture. You can nurture your son, daughter, boy or girl, but you cannot mature them! You can nurture a person into a mature politician but you cannot mature anybody into anything! Therefore, we must say:

(a) Mr. J.H. Mensah is a mature politician.

(b) I entered the University as a mature student.

(c) As a mature girl, you should know that boys could be dubious.

(d) We have seen the losers openly congratulating the visitors, which is the hallmark of mature politicians ...

The above notwithstanding it must be noted that 'the past participle of a verb' may be used as an adjective. But the point is that if a word that has the form of the past participle of a verb qualifies a noun that word is no more a verb but an adjective. Thus, in the following phrases the under- 
lined words are adjectives though they have the form of the past tense or past participle of the verb:

i) the captured armed robber

ii) the damaged vehicle

iii) the interested party

iv) the disappointed lover.

\section{PERSONA NON-GRATA}

A person is either persona grata or persona non-grata. It is incorrect to add the article a to either of the two expressions. In other words, it is not correct to say or write a persona grata or a persona non-grata. For example, if we say "Osama bin Laden is persona non-grata everywhere except in his hide-out", we mean he is not an acceptable person or is a person not welcome anywhere. Persona grata has the meaning of an acceptable person. As pointed out, the indefinite article a has no business in this usage

\section{THE LAST BUT NOT THE LEAST}

The behaviour of this phrase is like the preceding phrase persona non-grata. Normative English would not have an article but that appears to be the norm in West Africa. The last but not the least is heard on the lips of many academicians and it is ubiquitous in very many apparently scholarly newspaper articles. But the article the is unnecessary. The educated native speaker would normally say for example, "Last but not least we have in our midst our famous artiste Lionel Riche".

\section{UNIQUE}

This word is sufficient unto itself. Contrary to usage in West Africa the word unique does not go with an intensifier. We cannot say, "The Arrow of God is Achebe's most unique novel". The adjective most functioning as an intensifier here makes the phrase most unique tautological.

\section{VOICE OUT}

We voice an opinion, we never voice out an opinion. Like advocate the phrasal verb voice does not require a prepositional adjunct to make sense. Thus, the sentence, "We students must voice out our feelings about the introduction of school uniforms" is incorrect. We can say, for example, "We must voice our opinion about the wearing of school uniforms by university students.

\section{CONCLUSION}

We have not been concerned with General Semantics in this paper. Hence, our effort has not been exactly a forensic analysis which would then have been in consonance with Berthof's (1976) observation that "one of the principal slogans associated with General Semantics is that language should be a map for the territory of reality". General Semantics was created by a noble man of Polish origin, Alfred Korsybsky. Its approach to linguistic investigations was very popular in the 1940 s by reason of its extreme scientific nature. Berthoff notes in her article entitled From Problem Solving To A Theory Of Imagination that "General Semantics is a systemization of attitudes which are sometimes given the name scientism. Strong approbation is awarded measurement, statistical analysis, operational definitions etc". Such scientism has not been our approach in this paper for the reason stated at the beginning of our introduction.

Our concern has been with the unacceptable but passable usage of English in academia. Indeed, passabilty appears to be a very strong point with such nativisors as Bamgbose (1997) who postulates the so-called 'concept of innovation' and claims that "Language cannot remain static, and it is an aspect of growth and adaptation to cultural and linguistic environment that varieties must develop". Achebe (1975) without necessarily being supportive of this view opines that "the price a world language must be ready to pay is submission to many different kinds of use." Bamgbose and the purveyors of the concept of innovation appear to get further support from Akmajian et al (2003). Discussing the difference between the linguistic meaning of an expression and a given speaker's literal or non-literal use of an expression Akmajian et al say that “... in

46 Journal of Science and Technology, Vol. 28, No. 3, Dec., 2008 
talking about the linguistic meaning of an expression, we must note that meanings can vary across dialects and across individual speakers". Thus, Bamgbose (1997) ignores the contention of Quirk that "it is neither liberal nor liberating to permit learners to settle for lower standards than the best, and it is a travesty of liberalism to tolerate low standards which will lock the least fortunate into the least rewarding careers".

This paper is in agreement with Quirk's concern. We cannot settle docilely "for lower standards" in the name of innovation, no matter the merits. We need to know what the fluent speakers do with their language before we engage in linguistic adventures. Akmajian et al (2003), tell us that "whatever fluent speakers know of their language is a proper part of a description of that language". This truism must be acknowledged by us non-native speakers.

We would recommend that the nativisors accept only new descriptions peculiar to a particular people rather than accept purely grammatical, semantic and even orthographical misrepresentations as innovative additions to the English Language. Consequently, we see bedrock wisdom in the following words of Professor Ebenezer Okae Asare in an article entitled Reflections on Ghana's Educational System: Standards are Falling: "We cannot do without the ability to speak and write good English. Throughout the EU people are busily learning to read, speak and write English. English seems to be the language for the future". (Daily Graphic, May 9, 2007).

\section{REFERENCES}

Achebe, C. (1974a). Arrow of God, London, Heinemann Educational Books. Preface to Second Edition.

Achebe, C. (1975b). In: Noble, R.W. English Comprehension and Summary, London, Longman Group Ltd. p.29.

Akmajian, A. Demers, R.A. Farmer, A.K. and Harnish, R.M. (2003a), Linguistics, An Introduction to Language and communication,
New Delhi, Price-Hall of India Private Limited. p.215.

Akmajian, A. Demers, R.A. Farmer, A.K. and Harnish, R.M. (2003b), Linguistics, An Introduction to Language and Communication, New Delhi, Prince-Hall of India Private Limited. p.216.

Akmajian, A. Demers R.A. Farmer, A.K. and Harnish, R.M. (2003c), Linguistics, An Introduction to Language and Communication, New Delhi, Prince-Hall of India Private Limited, p.214.

Armah, K.O.O. (2004). "An Analytical Commentary On Some Telling Grammatical Errors On Some Frequency Modulation Stations In Kumasi, Ghana." Journal of Science and Technology, Vol. 24, Number 2, 2004, p.97.

Bamgbose, A. (1996a). Non-Native Englishes On Trial. In: Dakubu, K.M.E. (Editor) English In Ghana, Accra. A publication of The English Studies Association. Black Mask Publishers. p.13.

Bamgbose, A. (1996b). Non-Native Englishes On Trial. In: Dakubu, K.M.E. (Editor) English In Ghana, Accra. A Publication of The English Studies Association. Black Mask Publishers. p.12.

BBC English Dictionary (1992). London, BBC and Happer Collins Publishers Ltd.

Berthoff, A.E. (1976). From Problem-Solving to a Theory of Imagination. In: Graves, R.L. (Editor) Rhetoric And Composition, A Source Book for Teachers, Rochelle Park, New Jersey, Heyden Book Company, Inc. p.282.

Quirk, R. Greenbaum S. Leech, G. and Svartvik J. (1972). A Grammar of Contemporary English, London, Longman Group Limited. p.317. 